\title{
Colombian Caribbean mangrove dynamics: anthropogenic and environmental drivers
}

\author{
Ligia E. Urrego, Alexander Correa-Metrio, Catalina González-Arango
}

Ligia E. Urrego

leurrego@unal.edu.co

Departamento de Ciencias Forestales, Universidad Nacional del Colombia, Sede Medellín, Medellín, Colombia.

\section{Alexander Correa-Metrio}

Instituto de Geología, Universidad Nacional Autónoma de México, Ciudad de México, México.

\section{Gatalina González-Arango}

Departamento de Ciencias Biológicas, Universidad de los Andes, Bogotá, Colombia.
BOL. SOC. GEOL. MEX. 2018

VOL. 70 NO. 1

P. $133-145$

http://dx.doi.org/10.18268/BSGM2018v70nla8

Manuscript received: December 12, 2016 Corrected manuscript received: May 19, 2017 Manuscript accepted: Mav 25, 2017

\begin{abstract}
We review the main effects of sea level rise, salinity changes, and human disturbances on mangrove forest dynamics. The effects of these drivers on mangrove communities are evaluated at centennial time scales in the light of six palynological records from the Colombian Caribbean. Despite the accelerated rates of sea level rise, increases in sea surface and air temperatures, and decreases in precipitation of the last two centuries, mangroves have shown an increasing representation in pollen records at continental and marine locations of the region. In continental settings, such expansions have been related to the offsetting of sea levels by the increasing loads of fluvial sediments since $1850 \mathrm{AD}$, and by increases in autochthonous peat accumulation in San Andrés Island. Losses of mangrove cover in the past have been related to coastal erosion, regional droughts, and salinity increases. Such processes have commonly caused mangrove die-off or changes in forest species composition. When the substrate has become more saline, or sand sedimentation has increased significantly, the composition of mangrove communities has switched towards the dominance of Avicennia germinans at expenses of Rhizophora mangle. Resprout capacity of damaged stems of Avicennia germinans seems to have been the trait that has allowed this species to increase after strong and prolonged droughts, and occurrence of strong winds, tropical storms, and hurricanes. Human disturbances are represented either by the expansion of Laguncularia racemosa and Avicennia germinans and decreases of Rhizophora mangle, or by mangrove replacement by herbaceous vegetation (grasses or crops), especially the fern Acrostichum aureum. Around 1850 AD, mangroves and beach vegetation were replaced by coconut plantations in San Andrés Island, and in the Cispatá bay swampy areas were covered with rice crops. Although after 1900 $\mathrm{AD}$ these crops were abandoned because of a marine incursion, Laguncularia racemosa has prevailed so far indicating pervasive anthropogenic disturbances.
\end{abstract}

Keywords: mangrove forest, Caribbean Sea, climate change, salinity, deforestation, drought, sea level.

\section{RESUMEN}

Se realizó una revisión de los efectos del incremento en el nivel del mar, los cambios en la salinidad y las perturbaciones humanas sobre la dinámica de los manglares. Los efectos de estos factores se analizaron a escalas seculares en seis registros palinológicos tomados en el Caribe Colombiano. A pesar del incremento acelerado en el nivel del mar, los incrementos en las temperaturas del mar y del aire y las disminuciones en la precipitación en los dos últimos siglos, los manglares han aumentado su representación en los registros de palinológicos en varios sitios de la región, ubicados tanto en el continente como en las islas oceánicas. Tal expansión de los manglares se asocia con su capacidad de mantener el substrato contrarrestando el incremento en el nivel mar con el aumento en las cargas de sedimentos aluviales, desde 1850 AD en los sitios continentales, y con el aumento en la acumulación de turba autóctona en los suelos de la isla de San Andrés. Las pérdidas de manglares en el pasado, se asociaron a la erosión costera, y/o al efecto combinado del incremento regional en las sequías y en la salinidad. Estos procesos han ocasionado la muerte de los manglares o cambios en la composición de especies. Cuando se incrementan la salinidad del substrato y la deposición de arenas, pasan de ser manglares dominados por Rhizophora mangle a los dominados por Avicennia germinans. La capacidad de rebrote de los tallos dañados de Avicennia germinans parece ser el rasgo que le ha permitido a esta especie expandirse después de la ocurrencia de sequias intensas y prolongadas y de vientos fuertes, tormentas tropicales y huracanes. Las perturbaciones humanas se representaron por la expansión de Laguncularia racemosa y Avicennia germinans a expensas de Rhizophora mangle, o por el reemplazo de la vegetación arbórea por vegetación herbácea (pastizales o cultivos) y especialmente dominada por el helecho Acrostichum aureum. Alrededor de $1850 \mathrm{AD}$, los manglares y al vegetación de playa fueron reemplazados por plantaciones de coco en la isla de San Andrés y en la bahía de Cispatá las áreas pantanosas fueron cubierta con cultivos de arroz. Aunque después de 1900 AD se abandonaron estos cultivos debido a una incursión marina, ha prevalecido la dominancia de Laguncularia racemosa en los registros de polen indicando la intervención humana permanente desde entonces

Palabras clave: Cambio climático, salinidad, deforestación, sequía, nivel del mar. 


\section{Introduction}

Mangroves are forest ecosystems that grow on the ocean-continent ecotone. They are important not only because of the goods and services they provide to human communities, but also because of their role as nurseries for fauna. In addition, like many other wetlands, they are significant sinks of carbon and act as coastal protective barriers against storms and hurricanes. Mangrove forest dynamics are determined by oceanic, atmospheric, and terrestrial drivers. Whereas the latitudinal distribution of mangroves is bounded by minimum air temperatures, precipitation seasonality, intertidal range, and geomorphological settings play critical roles at determining the distribution of mangroves at more regional geographic scales (Krauss et al., 2008).

The sea-level increase that has characterized last century has been identified as the main threat to the stability and persistence of modern mangroves (Alongi, 2015). However, decreasing precipitation and increasing temperatures are also important threats as they cause salinization of soils and pore water, causing substantial decreases in productivity and biodiversity of mangrove forests (Alongi, 2008; Gilman et al., 2008). Changes in the frequency and intensity of extreme events such as storm surges and hurricanes have also been identified as important factors affecting the integrity and health of mangrove ecosystems.

The sedimentary dynamics of areas occupied by mangroves are critical to offsetting some of the deleterious effects of sea level rise on mangrove forests. Whereas coastal erosion processes related to sea-level rise occur in zones impacted directly by wave energy, sediment input may cause progradation of the surface (Parkinson et al., 1994; Krauss et al., 2014). Biotic processes such as increases in the root mat may also contribute to elevate the surface, representing another important mechanism for mangroves to adjust to sea level rise (Mckee et al., 2007). Thus, accretion of sediments by mangroves may counteract sea-level rise if their rates are similar. Conversely, if rates of sea-level rise are higher than accretion rates, and there is available space, mangrove ecosystems may migrate landward. When coastal erosion causes significant loss of land or when landward accommodation space is limited by infrastructure or other non-suitable conditions, a net loss of mangrove area occurs.

Based on future climatic scenarios of the IPCG (2013), several authors have postulated important changes in distribution and structure of mangrove ecosystems by the end of this century (e.g. Krauss et al., 2014; Alongi, 2015; Ellison, 2015). Changes in forest structure, composition, and function will be mostly associated with increases in sea surface temperature, atmospheric $\mathrm{CO}_{2}$ concentrations, sea level, and frequency of extreme meteorological events. Also, changes in precipitation and substrate salinity, and unavailability of landward sites for mangrove colonization, are expected to substantially impact these ecosystems. The Caribbean and Central America are expected to face the biggest losses of mangrove areas in the world. Negative impacts of both sea level and temperature rise combined with decreasing precipitation and related river discharges are expected. The combination of these factors will cause net losses in the stands of the three main mangrove species present in the Caribbean (Rhizophora mangle, Avicennia germinans, Laguncularia racemosa) (Record et al., 2013).

Because of the specific environmental preferences of mangrove species, their pollen record along sediment cores can be used to reconstruct past changes of sea level, precipitation, and salinity (Engelhart et al., 2007). Rhizophora mangle dominates fringe mangroves closer to shores, and has been recognized as an indicator of coastal line displacements. Avicenna germinans tolerates high salinities, and is therefore considered a good indicator of coastal drought and evaporative environments. On the other hand, the presence of pollen grains of Laguncularia racemosa and/or spores of the fern Acrostichum aureum may represent open canopies created by either natural or anthropogenic disturbances (Medina et al., 1990). Because the establishment of mangrove populations requires coasts protected from direct wave impact (Hog- 
arth, 1999), rapid and strong displacements of coast lines may not be accurately reconstructed based solely on mangrove pollen spectra. In such cases, the pollen of marsh vegetation is a good indicator of environmental variability (e.g. González and Dupont 2009). In fact, pollen of Amaranthaceae, Cyperaceae and Poaceae has been used to reconstruct past sea-level fluctuation (Hodell et al., 1991; Higuera-Gundy et al., 1999; González and Dupont, 2009). Other taxa such as Batis maritima, Sesuvium portulacastrum, and herbaceous Asteraceae and Fabaceae taxa are abundant along beaches, and their pollen in sedimentary sequences usually indicates environmental stages prior to mangrove establishment (e.g. Peros et al., 2007; Urrego et al., 2013).

At millennial time scales, mangrove ecosystems have expanded and contracted in response to both eustatic and climatic changes. For instance, through the last deglaciation, the Caribbean was characterized by arid and cool conditions, and lower-than-present sea levels (Hodell et al., 1991; Curtis et al., 1998; Higuera-Gundy et al., 1999; Haug et al., 2001). Given this environmental scenario, only spared patches of mangroves were recorded worldwide (Woodroffe and Grindrod, 1991). At the beginning of the Holocene, around $11000 \mathrm{yr}$ BP, fast sea level rise and increases in air temperature and precipitation (Haug et al., 2001) facilitated the earliest mangrove colonization in several places, as recorded in the Panamá Basin (González et al., 2006). Around 6000 BP the relative rapid decline of sea level led to the formation of several Caribbean coastal lakes, lagoons, estuaries, and back swamps that were colonized by mangroves (e.g, Raasveldt and Tomic, 1958; Hendry and Digerfeldt, 1989; Hodell et al., 1995; Curtis et al., 1998; Higuera-Gundy et al., 1999; Ramcharan and McAndrews, 2006; Peros et al., 2007; Wooller et al., 2007; Monacci et al., 2009, 2011; Carrillo-Bastos et al., 2010; Urrego et al., 2013; Joo-Chang et al., 2015).

The major expansion of mangrove forests during the Holocene in the Caribbean region took place around $4000-3000$ yr BP, when sea levels sta- bilized, reaching modern conditions (e.g. Ellison, 1996; Rull et al., 1999; Urrego et al., 2013; Cohen et al., 2016). Precipitation and river discharges, although variable, probably contributed to stabilize sediment input and salinity in the newly mangrove-colonized areas. However, the decreasing precipitation trend in the northern Neotropics and increasing climatic variability, probably associated with El Niño-Southern Oscillation (ENSO) (Haug et al., 2001), caused several severe droughts along the Caribbean coasts, from Mexico to Venezuela. These ENSO-related droughts caused the decline of flooding events (Ramcharan and McAndrews, 2006), and in turn reductions in mangrove extensions. Alternatively, mangroves forests experienced compositional changes with dominance of saline tolerant species (e.g. Avicennia germinans) (Ramcharan and McAndrews, 2006; Wooler et al., 2007; Carrillo-Bastos et al., 2010; Monacci et al., 2011). There is growing evidence of human populations larger than previously thought in South America since the early Holocene to Pre-Columbian times (Goldberg et al., 2015). Thus, human activities have played an important role as a disturbance factor to natural ecosystems through the last millennia. However, the strongest changes in natural resources associated with anthropogenic factors have been recorded during the last few centuries, especially after the industrial revolution by the end of the eighteenth century. Besides land use changes that have caused deforestation worldwide, other human activities have caused an increase of greenhouse gases in the atmosphere (mainly $\mathrm{CO}_{2}, \mathrm{CH}_{4}$, and $\mathrm{N}_{2} \mathrm{O}$ ), dramatically affecting climate. Also, the biogeochemical cycles of crucial elements, such as carbon, nitrogen, phosphorous, and sulfur, have been altered by anthropogenic activities (Steffen et al., 2011), driving unprecedented losses of biodiversity. Given this environmental scenario, the Anthropocene has been proposed as a new geological epoch characterized by the deep imprint of humans on the Earth system, although it has not been formally defined. During the last $\sim 200$ years environmental changes associated with human activities have taken place in an accelerated manner, 
with greenhouse gases in the atmosphere reaching record concentrations (Crutzen and Stoemer, 2000; Steffen et al., 2011). Thus, this time interval offers a good scenario for studying the interplay of human and natural stressors on mangrove ecosystems in the Colombian Caribbean. Through the use of palynological evidence we illustrate the disturbance patterns that have characterized the evolution of regional mangrove ecosystems, highlighting the high potential of anthropogenic activities to disrupt ecological and environmental dynamics.

\section{The sedimentary record of the Colombian Caribbean mangroves}

\subsection{THE COLOMBIAN GARIBBEAN AND THE STUDY SITES}

The Colombian Caribbean is a 1760-km-long coastline that extends from the Gulf of Urabá, northwestern Colombia, to the Guajira Peninsula, close to the Gulf of Venezuela (Figure 1). Warm climates characterize the region, whereas the precipitation is modulated by a gradient that goes from wet (mean annual precipitation of $2500 \mathrm{~mm}$, Gulf of Urabá) to arid conditions (mean annual precipitation of $550 \mathrm{~mm}$, Guajira Peninsula). The Intertropical Convergence Zone (ITCZ) modulates the bimodal distribution of precipitation and consequently the fluvial sediment supply to the coastal environments. Our review of the evolution of Colombian Caribbean mangrove forests is based on six sedimentary records from four locations in the Colombian Caribbean: core Calancala from the Guajira Peninsula (Urrego et al., 2013), cores La Flotante and Navío from Cispatá Bay (Castaño et al., 2010), cores Candelaria and El Uno from the Gulf of Urabá (this study), and core Honda Bay from San Andrés Island (González et al., 2010). Guajira Peninsula (northernmost Colombia): The Calancala core (11 $\left.{ }^{\circ} 34^{\prime} 30^{\prime} \mathrm{N}, 72^{\circ} 52^{\prime} 36^{\prime \prime} \mathrm{W}\right)$ was retrieved from a branch of the Ranchería River delta that is the main source of freshwater of the
Guajira Peninsula. The river reaches the coastal plain near the city of Riohacha (Figure 1), and the Caribbean Low Level Jet that blows parallel to the Guajira coast induces coastal upwelling (Andrade and Barton, 2005). The sediments of the area are mostly alluvial, underlain by aeolian sediments. The coastal sedimentary plain is slightly undulated and is mainly fed by alluvial sediments from the Cesar and Ranchería rivers. An estuary that opens only during the short rainy season is formed by the river mouth (Instituto Geográfico Agustín Codazzi, IGAC, 2009).

Gulf of Urabá: The Gulf of Urabá is the largest semi-enclosed sea inlet along the Colombian $\mathrm{Ca}$ ribbean coastline. The coastline of the gulf is characterized by low intertidal ranges, whereas rivers such as the Atrato at the west and the Turbo at the east exert a strong influence on the geomorphic dynamics because of their high discharge. Thus, the coastline is heavily affected by sediment accumulation and erosion caused by rising sea levels, alluvial sediment transport, and biogenic factors (Bernal et al., 2005). Because of the high fluvial input, soil salinity and interstitial salinity are very low. While the Candelaria Bay core is located on the west side of the gulf close to the Atrato River delta, El Uno Bay core is placed on the east coast of the gulf close to the mouth of the Turbo River (Figure 1).

Cispatá Bay: This bay is located on the northwestern coast of Colombia and encloses a big lagoon complex surrounded by the largest mangrove area of the region. The Sinú River is the main freshwater source, and thus the dynamics of the delta exert high influence on the regional geomorphology. Indeed, the delta has changed its position six times during the last $\sim 350$ years. Lagoons La Flotante

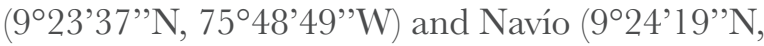
$75^{\circ} 51^{\prime} 41^{\prime \prime} \mathrm{W}$ ), where the cores were retrieved, are part of this system (Figure 1). Regional mean annual precipitation is $1338 \mathrm{~mm}$ (Serrano, 2004; Castaño et al., 2010).

San Andrés Island: The island is part of the archipelago comprised of San Andrés, Providencia, and Santa Catalina Islands, lying about $800 \mathrm{~km}$ 


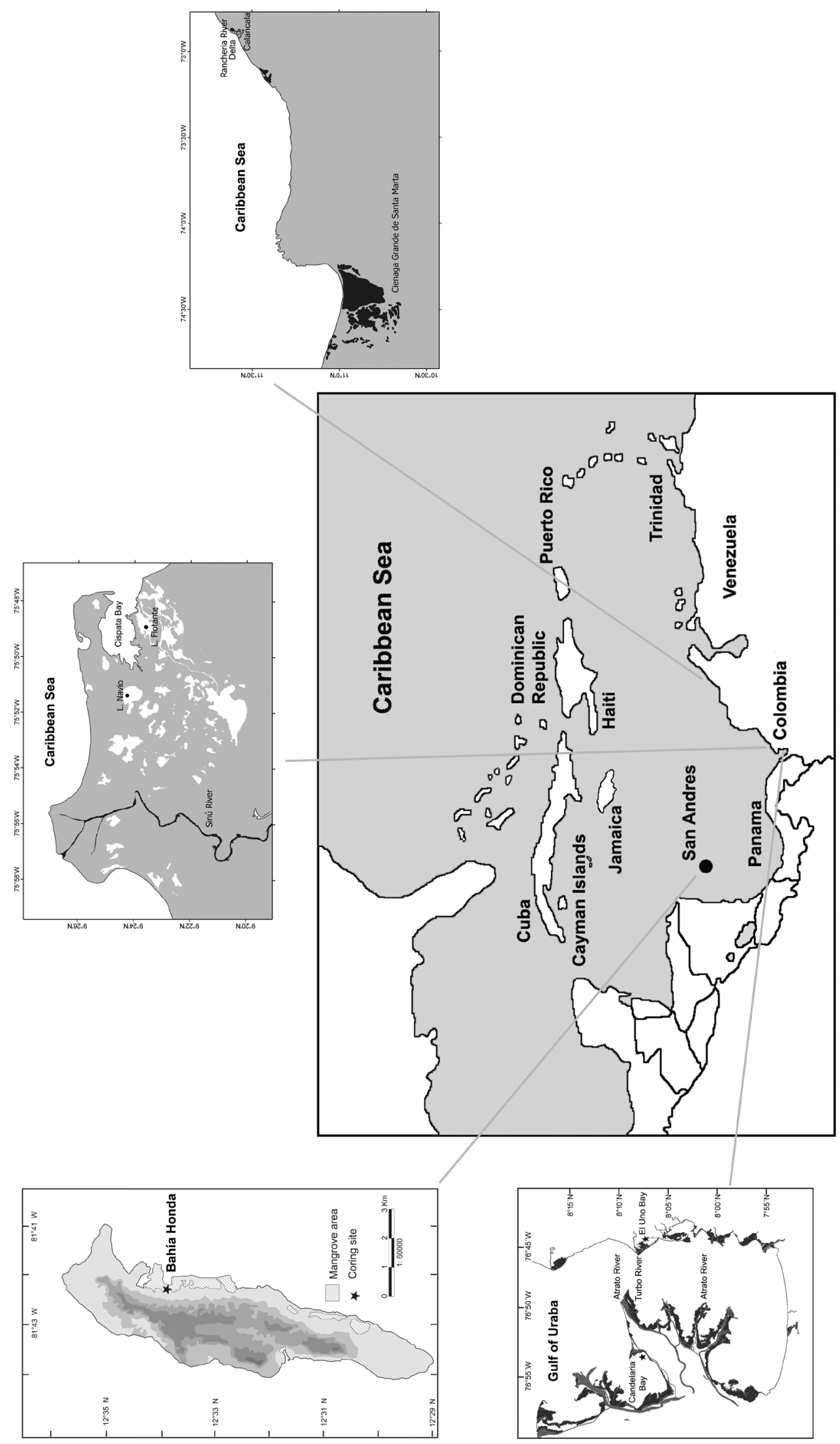


from the Colombian continental coast and about $150 \mathrm{~km}$ off Nicaragua (IGAC, 1986). The Honda Bay $\left(12^{\circ} 33^{\prime} \mathrm{N}, 81^{\circ} 42^{\prime} \mathrm{W}\right)$ is located on the eastern coast of the island, and is surrounded by a broad mangrove area, with direct communication with the sea on an emerged marine terrace. The mean annual precipitation is $1900 \mathrm{~mm}$ (Díaz et al., 1995).

\subsection{SEA LEVEL RISE AND GEOMORPHOLOGICAL DYNAMICS}

Following the worldwide trend, sea levels have risen steadily along the Caribbean Colombian coast through the last 200 years. The rates of mean regional sea level rise have been estimated at $0.20 \mathrm{~cm} / \mathrm{yr}$ from 1907 to 1997 , and $0.36 \mathrm{~cm} /$ yr for the last five decades (data from two recording stations: Cristóbal, Panama and Cartagena, Colombia, Torres et al., 2008). This sea level rise record coincides with the trends of climate indi- ces (SOI and NOI) reported by Mendelson et al. (2005).

Since the end of the Little Ice Age $(\sim 1850$ AD) to present, mangroves have shown an increasing representation at several locations of the Colombian Caribbean (Figure 2): El Uno and Candelaria bays in the Gulf of Urabá, La Flotante and Navío in the Cispatá Bay, and Calancala in the Guajira Peninsula. Such expansions have been mainly characterized by a steady increase of Rhizophora mangle pollen and to a lesser extent Avicennia germinans and Laguncularia racemosa. The mean sedimentation rates of these cores have been high since 1850 AD (Figure 3). In El Uno and Candelaria bays the mean annual sedimentation rates have been 0.79 and $0.89 \mathrm{~cm} / \mathrm{yr}$, respectively, and in the Cispatá bay these rates were 0.33 and $0.26 \mathrm{~cm} /$ yr in La Flotante and Navío cores, respectively (Castaño et al., 2010). In contrast, a sedimentation rate of $1.44 \mathrm{~cm} / \mathrm{yr}$ was recorded for the Calanca-

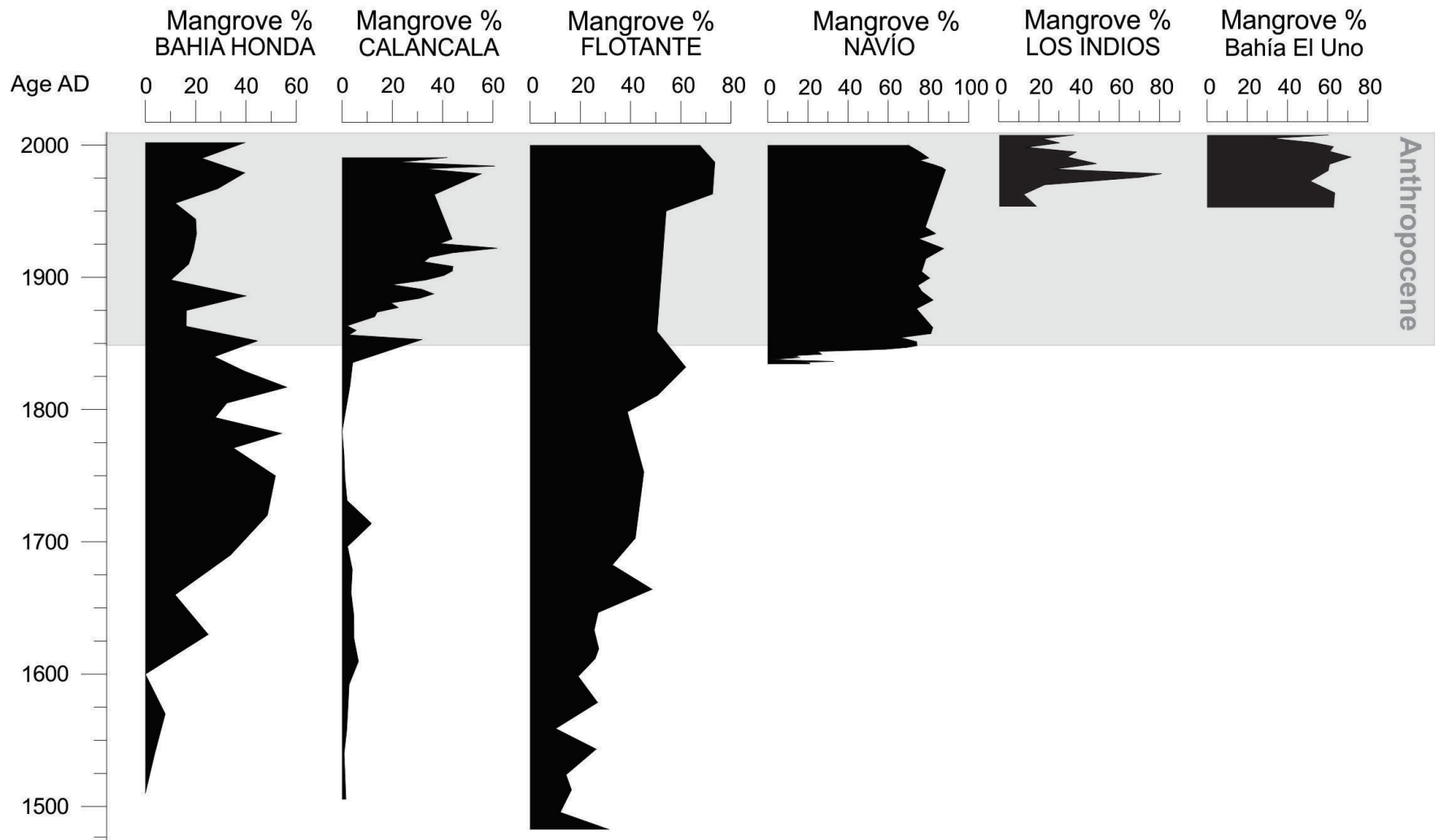

Figure 2 Diagrams of pollen percentages of mangroves from analyzed sediment cores from the Colombian Caribbean during the Anthropocene. A generalized increase of mangrove forests since $1850 \mathrm{AD}$ and especially after 1950 is recorded in all of them. 


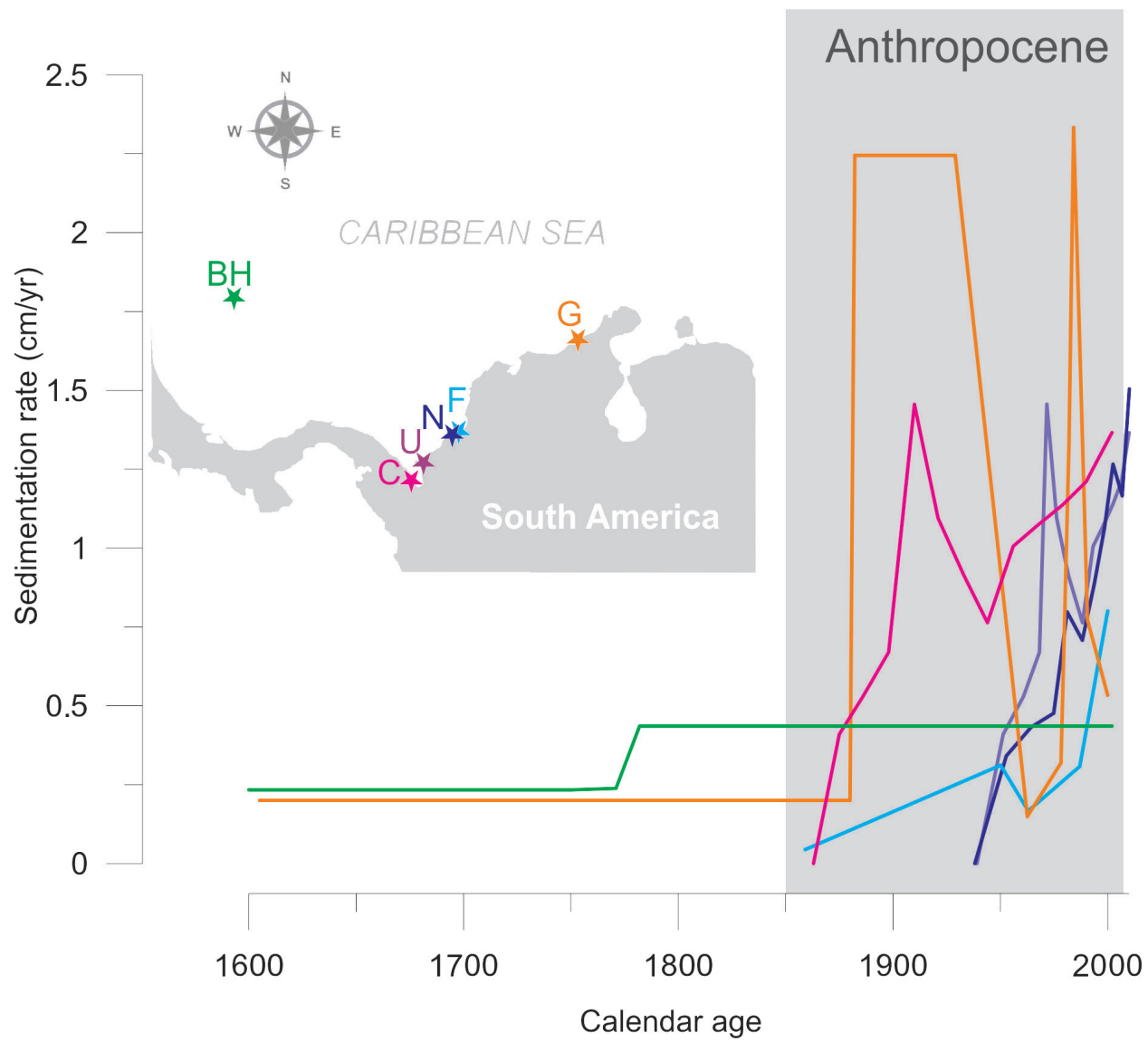

Figure 3 Comparison of sedimentation rates of mangroves from analyzed sediment cores from the Colombian Caribbean during the Anthropocene. Note the increase of sedimentation rates in the continental records located close to deltas, derived from changes in river discharges.

la core (Urrego et al., 2013). High sedimentation rates are related to the high sediment loads of the rivers, a common feature of deltas (Turbo River, $403.29 \mathrm{t} \mathrm{km}^{2} \mathrm{yr}^{-1}$; Atrato River, $315 \mathrm{t} \mathrm{km}^{2} \mathrm{yr}^{-1}$; and Sinú River, $\left.167 \mathrm{t} \mathrm{km}^{-2} \mathrm{yr}^{-1}\right)$. It has been suggested that Caribbean mangroves could tolerate rates of sea level rise of about $0.08-0.09 \mathrm{~cm} / \mathrm{yr}$, and would be at risk of disappearing with increases between 0.09 and $0.12 \mathrm{~cm} / \mathrm{yr}$ (Ellison and Stoddart, 1991; Ellison, 1993; Field, 1995). However, our data show that mangroves in the Colombian Caribbean have not only survived high mean rates of sea level rise (between 0.20 and $0.36 \mathrm{~cm} / \mathrm{yr}$ ) but have expanded in territory. Regional mangrove expansion has probably benefited from high fluvial sediment inputs that provide materials to offset sea-level rise (Parkinson et al., 1994; Krauss et al., 2014).
Despite the high sedimentation rates recorded at the Atrato River delta, there were differences in both sedimentation rates and mangrove ecological succession between the two localities sampled in the region. Differences between these locations (Candelaria and El Uno bays) are likely modulated by geomorphology, the specific location of the coring sites within the delta, and the sediment load that each river branch may carry according to the size of the drainage basin. At Candelaria Bay, north of the Atrato River Delta (Figure 2), mangrove pollen shows a decreasing trend towards the present, despite the high sediment load transported by the Atrato River. However, the bay is in direct contact with the sea, receiving high impact from waves (Suárez et al., 2015). This marine influence and the increasing sea level have caused coastal erosion and local mangrove losses. Con- 
trastingly, El Uno Bay, located on the eastern side of the Gulf of Urabá (Figure 2), shows an expansion of mangrove forests during the last two centuries, probably related to a local reconfiguration of the coastal geomorphology. At this site, the Turbo River spit is advancing, causing a natural closure of the bay, which in turn is becoming a coastal lagoon more suitable for mangrove expansion. The eastern side of the Gulf of Urabá, where El Uno Bay lies, receives more sediment than the western side, mostly related to littoral drift and a lesser impact of strong winds (Suárez et al., 2015). This is also the case of Cispatá Bay where changes in mangrove and marsh vegetation reflect at least four migrations of the Sinú River delta. Hydrological and sedimentological dynamics changed the relative position of the lagoons with respect to the shorelines and the river delta. These examples show the critical role of coastal protection and/or geomorphological position for mangroves coping with sea level rise.

\subsection{INGREASED SOIL AND PORE-WATER SALINITY AFFEGTING MANGROVE SUBSTRATE}

Precipitation increases have contributed to the resilience of Caribbean mangrove communities to sea level rise. During periods of high rainfall, mangroves face the indirect effects of increased erosion rates, high continental sediment loads and lower soil salinity. In contrast, when rainfall decreases for longer than the regular dry season (e.g., during strong El Niño events), mangrove forests might die off or change their species composition. Apart from the obvious consequences of rainfall reduction and temperature increases, droughts cause a substantial increase in both soil and interstitial salinity. When the substrate becomes more saline, mangrove community composition switches towards the dominance of Avicennia germinans, which is the most salt tolerant mangrove species (Sobrado, 2000). Despite its low representation in mangrove pollen spectra, during prolonged droughts this species increases at the expense of Rhizophora mangle, sometimes becoming the dominant species of the forest stand (Ellison, 1996; Monacci et al., 2009), a process that has been observed in some instances in the Colombian Caribbean (Figure 2, La Flotante, Calancala and Honda Bay; Castaño et al., 2010; González et al., 2010; Urrego et al., 2013). Similar high-salinity conditions can also be produced by increases in sand sedimentation that cause relief increases, but that are easily drained. This process combined with high evaporation rates and shallow water causes increases of soil salinity, and therefore the turnover from Rhizophora mangle to Avicennia germinans (Twilley et al., 1999; López-Medellín et al., 201 1; Monacci et al., 2011). At El Uno Bay, high deposition of sand was recorded in the 1950s when the Turbo River bed was artificially deviated. This anthropogenic intervention changed the local sedimentary dynamics and the composition of the mangrove community, turning a typical fringe mangrove stand into a typical inland community (López-Medellín et al., 2011). Thus, the dominance of Avicennia germinans can either be a signal of mangroves adjusting to current climate change (e.g. López-Medellín et al., 2011), or alternatively a local change in the geomorphology and the sediment dynamics as shown for El Uno Bay.

Several palynological records have shown strong reduction of Caribbean mangroves since the Medieval Warm Period, possibly as a result of decreasing rainfall. Extreme events such as storm surges and hurricanes that have been recorded in several sites have also changed the mangrove forest composition reflected in the sedimentary sequences (López-Medellín et al., 2011; McCloskey and Liu, 2013). Increases in Avicennia germinans have been reported as indicators of early colonization after hurricanes and windstorms at Honda Bay (Figure 2) (González et al., 2010) and in La Guajira Peninsula (Bernal et al., 2016). The climates of both regions were characterized by a strong and prolonged dry season after the occurrence of the extreme event. Increases in Avicennia germinans were probably the result of the high resprout capacity of damaged stems and the increase of light avail- 
ability caused by massive defoliation (Smith $e t$ al., 1994; Baldwin et al., 2001). Avicennia germinans has been regarded as the best-adapted mangrove species to conditions associated with current climate change (increasing temperatures, salinity, and drought frequency; Field, 1995; Snedaker, 1995). Thus, its expansion during the last century in San Andrés Island (Urrego et al., 2009; González et al., 2010) and other localities (Behling et al., 2001) is related not only to droughts and high salinity, but also the increased frequency of extreme storms and winds.

\subsection{HUMAN DISTURBANGES}

Human activities have affected the extension and composition of most Caribbean mangrove forests, obscuring the signals of current climate change on these ecosystems and therefore on their pollen spectra. Through the last few decades, substantial losses of mangrove forest extensions have been attributed to human disturbances (Rull et al., 1999; Martinuzzi et al., 2009). Nevertheless, clear evidence of the long-term changes, such as pollen records, are rather scarce. Human disturbances to mangrove ecosystems are represented by either the expansion of Laguncularia racemosa (Benfield $e t$ al., 2005) and Avicennia germinans at the expense of Rhizophora mangle, or mangrove replacement by herbaceous vegetation (grasslands or crops), especially the fern Acrostichum aureum (Medina et al., 1990). However, these responses have proven highly dependent on species' differential tolerance to soil salinity and local conditions.

Around 1850 AD, at Honda Bay, San Andrés Island, Colombian Caribbean, mangroves and beach vegetation were replaced by coconut plantations (González et al., 2010), a practice that expanded widely through the Caribbean since that time (Parsons, 1985). The proliferation of Laguncularia racemosa after $1850 \mathrm{AD}$ is also an indication of disturbances, especially during the last few decades, not only in San Andrés Island but also on the continental coastlines of the Colombian Caribbean (La Flotante and Navío localities from the Cispatá Bay, Castaño et al., 2010; and Calancala in the Guajira Peninsula, Urrego et al., 2013). While in San Andrés Island, Zea mays pollen indicating its cultivation was detected in the surroundings of the mangrove forest, in Cispatá, the pollen spectra revealed swampy areas covered by rice crops. Although after 1900 AD these crops were abandoned because of a marine incursion, Laguncularia racemosa has prevailed so far as an indication of pervasive anthropogenic disturbances. In the Gulf of Urabá, mangrove conversion into grasslands for cattle raising is indicated at El Uno Bay (Figure 2). Also, assessments of current vegetation in the Gulf of Urabá have reported expansions of Avicennia germinans, likely as a result of human disturbance resulting in higher sedimentation rates (Suárez et al., 2015).

\section{Conclusions}

The strongest changes in natural resources associated with anthropogenic factors have been recorded during the last few centuries, especially after the industrial revolution by the end of the eighteenth century. Thus, the need for defining a new geological epoch (Anthropocene) has been identified. In the Colombian Caribbean during this time period, pollen records from sedimentary sequences suggest vegetation changes mostly affected by three main drivers (sea level rise, salinity changes, and human disturbances). During the last two centuries, despite the accelerated rates of sea level rise, increases in sea surface and air temperatures, an invigorated ENSO, and precipitation decreases, mangroves have shown an increasing representation in pollen records at several continental locations of the Colombian Caribbean. Such is the case of El Uno and Candelaria bays in the Gulf of Urabá, La Flotante and Navío in the Cispatá Bay, and Calancala in the Guajira Peninsula. Such expansions are probably associated with the offsetting of growing sea levels by the increasing loads of fluvial sediments since 1850 AD. Mangrove communities of San Andrés Island that grow on carbonate substrates also expanded during this 
period, and in this case, sea level rises were counterbalanced by the increases in autochthonous peat accumulation. At local scales, differences in mangrove responses to sea level rise are modulated by geomorphology, specific location of the coring sites within deltas, sediment input, or coastal erosion.

When rainfall decreases for longer than the regular dry season (e.g. during strong El Niño intervals) mangroves forests might die off or suffer changes in species composition. During extremely dry climatic episodes, there are substantial increase in soil temperature and salinity, and interstitial salinity. This salinity increase causes mangrove community composition to switch towards the dominance of Avicennia germinans, which is the most salt-tolerant mangrove species. Anthropogenic changes in the river courses have also been associated with similar floristic and compositional changes, turning a typical fringe mangrove forest into a typical inland community. Increases in Avicennia germinans have also been associated with strong and prolonged droughts after the occurrence of extreme events such as strong winds, tropical storms, and hurricanes. High resprout capacity of mangrove species' damaged stems, and the increase of light availability caused by massive defoliation, are a reasonable explanation for mangrove forest expansion after extreme events. Human disturbances are represented either by the expansion of Laguncularia racemosa and Avicennia germinans at the expense of Rhizophora mangle, or by the replacement of mangrove by herbaceous vegetation (grasslands or crops), especially the fern Acrostichum aureum. This footprint has also been recorded in the palynologycal record of the studied Colombian mangroves.

\section{Acknowledgements}

The research presented through this revision has been funded by Universidad Nacional de Colombia. We are indebted with local communities that have granted us access to the study sites and facilitated the fieldwork logistics.

\section{References}

Alongi, D.M., 2008, Mangrove forests: Resilience, protection from tsunamis and responses to global climatic change: Estuarine, Coastal Shelf Science, 76, 1-13.

Alongi, D., 2015, The Impact of Climate Change on Mangrove Forests: Current Climate Change Reports, 1, 30-39.

Andrade, G., Barton, E.D., 2005, The Guajira upwelling system: Continental Shelf Research, 25, 1003-1022.

Baldwin, A., Egnotovich, M., Ford, M., Platt, W., 2001, Regeneration in fringe man-grove forests damaged by Hurricane Andrew: Plant Ecology, 157, 149-162.

Behling, H., Cohen, M.G.L., Lara, R.J., 2001, Studies on Holocene mangrove ecosystem dynamics of the Braganca Península in north-eastern Pará, Brazil: Palaeogeography, Palaeoclimatology, Palaeoecology, 167, 225-242.

Benfield, S.L., Guzman, H.M., Mair, J.M., 2005, Temporal mangrove dynamics in relation to coastal development in Pacific Panama: Journal of Environmental Management, 76, 263-276.

Bernal, G., Montoya, L.J., Garizábal, G., Toro, M., 2005, La complejidad de la dimensión física en la problemática costera del Golfo de Urabá, Colombia: Gestión y Ambiente, 8, 123-135.

Bernal, G., Osorio, A.F., L. Urrego, L., Peláez, D., Molina, E., Zea, S., Montoya, R.D., Villegas, N., 2016, Occurrence of energetic extreme oceanic events in the Colombian Caribbean coasts and some approaches to assess their impact on ecosystems: Journal of Marine Systems, 164, 85-100.

Carrillo-Bastos, A., Islebe, G.A., TorrescanoValle, N., González, N.E., 2010, Holocene vegetation and climate history of central Quintana Roo, Yucatán Peninsula, Mexico: 
Review of Palaeobotany and Palynology, 160, 189-196.

Castaño, A.R., Urrego, L.E., Bernal, G.R., 2010, Dinámica del manglar en el complejo lagunar de Cispatá (Caribe colombiano) en los últimos 900 años: Revista de Biología Tropical, 58, 1347-1366.

Cohen, M.C.L., Lara, R.L., Guevas, E., Oliveras, E.M., Da Silveira-Sternberg, L., 2016, Effects of sea-level rise and climatic changes on mangroves from southwestern littoral of Puerto Rico during the middle and late Holocene: Catena, 143, 187-200.

Crutzen, P.J., Stoermer, E.F., 2000, The "Anthropocene": IGBP Newsletter, 41, $17-18$.

Curtis, J.H., Brenner, M., Hodell, D.A, Richard, A., Balser, R.A., Islebe, G.A., Hooghiemstra, H., 1998, A multiproxy study of Holocene environmental change in the Maya Lowlands of Peten, Guatemala: Journal of Paleolimnology, 19, 139-159.

Díaz, J.M., Díaz-Pulido, G., Garzón-Ferreira, J., Geister, J., Sánchez, J.M., Zea, S., 1995, Atlas de los arrecifes coralinos del Caribe colombiano. I. Complejos arrecifales oceánicos: Serie de Publicaciones Especiales 2, Instituto de investigaciones marinas $\mathrm{y}$ costeras (INVEMAR), Santa Marta, 85 p.

Ellison, J.G., 1993, Mangrove retreat with rising sea-level, Bermuda: Estuarine Coastal and Shelf Science, 37, 75-87.

Ellison, J.C., 1996, Pollen evidence of Late Holocene mangrove development in Bermuda: Global Ecology and Biogeography, 5, 315-326.

Ellison, J.C., 2015, Vulnerability assessment of mangroves to climate change and sealevel rise impacts: Wetlands Ecology and Management, 23, 115-137.

Ellison, J.C., Stoddart, D.R., 1991, Mangrove ecosystem collapse during predicted sea level rise: Holocene analogues and implications: Journal of Coastal Research, 7, 151-165.
Engelhart, S.E., Horton, B.P., Roberts, D.H., Bryant, C.L., Corbett, D.R., 2007, Mangrove pollen of Indonesia and its suitability as a sealevel indicator: Marine Geology, 242, 65-81.

Field, C.D., 1995, Impact of expected climate change on mangroves: Hydrobiologia, 295, 75-81.

Gilman, E.L., Ellison, J., Duke, N.C., Field, C., 2008, Threats to mangroves from climate change and adaptation options: a review: Aquatic Botany, 89, 237-50.

Goldberg, A., Mychajliw, A.M., Hadly, E., 2015, Post-invasion demography of prehistoric humans in South America: Nature, 532, 232-235.

González, C., Dupont, L., 2009, Coastal vegetation evidence for sea level changes associated with Heinrich events: PAGES News, 17, 70-72.

González, C., Urrego, L.E., Martínez, J.I., 2006, Late Quaternary vegetation and climate change in the Panama Basin: Palynological evidence from marine cores ODP 677B and TR 163-38: Palaeogeography, Palaeoclimatology, Palaeoecology, 234, 62-80.

González, C., Urrego, L.E., Martínez, J.I., Polanía, J., Yokoyama, Y., 2010, Mangrove dynamics in the southwestern Caribbean since the 'Little Ice Age': a history of human and natural disturbances: The Holocene, 20, 849-861.

Haug, G.H., Hughen, K.A., Sigman, D.M., Peterson, L.C., Röhl, U., 2001, Southward migration of the Intertropical Convergence Zone through the Holocene: Science, 293, 1304-1308.

Hendry, M.D., Digerfeldt, G., $\quad 1989$, Palaeogeography and palaeoenvironments of a tropical coastal wetland and offshore shelf during Holocene submergence, Jamaica: Palaeogeography, Palaeoclimatology, Palaeoecology, 73, 1-10.

Higera-Gundy, A., Brenner, M., Hodell, D.A., Curtis, J.H., Leyden, B.W., Binford, M.W., 
1999, A 10,300 ${ }^{14} \mathrm{C}$ yr record of climate and vegetation change from Haiti: Quaternary Research, 52, 159-170.

Hodell, D., Curtis, J., Jones, G., Higuera-Gundy, A., Brenner, M., Binford, M.W., Dorsey, K., 1991, Reconstruction of Caribbean climate change over the past 10,500 years: Nature, 352, 790-792.

Hodell, D.A., Curtis, J.H., Brenner, M., 1995, Possible role of climate in the collapse of Classic Maya civilization: Nature, 375, 391-394.

Hogarth, P.J., 1999, The Biology of Mangroves: Oxford, New York, USA, 240 p.

Instituto Geográfico Agustín Codazzi (IGAG), 1986, San Andrés y Providencia, aspectos geográficos: Instituto Geográfico Agustín Codazzi, Bogotá, 156 p.

Instituto Geográfico Agustín Codazzi (IGAC), 2009, Estudio general de suelos y zonificación de tierras del departamento de La Guajira: Imprenta Nacional de Colombia, Bogotá, 490 p.

Joo-Chang, J.G., Islebe, G.A., Torrescano-Valle, N., 2015, Mangrove history during middleand late-Holocene in Pacific south-eastern Mexico: The Holocene, 25,651-662.

Krauss, K.W., Lovelock, C.E., McKee, K., LópezHoffman, L., Ewe, S.M.L., Sousa, W.P., 2008, Environmental drivers in mangrove establishment and early develop-ment: a review: Aquatic Botany, 89, 105-127.

Krauss, K.W., McKee, K.L., Lovelock, C.E., Gahoon, D.R., Saintilan, N., Reef, R., Chen, L., 2014, How mangrove forests adjust to rising sea level?: New Phytologist, 202, 19-34.

Intergovernmental Panel on climate change (IPCG), 2013, Climate Change 2013: The Physical Science Basis. Contribution of Working Group I to the Fifth Assessment Report of the Intergovernmental Panel on Climate Change, in Stocker, T.F., Qin, D., Plattner, G.-k., Tignor, M., Allen, S.k., Boschung, J., Nauels, A., Xia, Y., Bex, V., Midgley, P.M. (eds.), Cambridge University
Press, United Kingdom ad USA, 1535 p.

López-Medellin, X., Ezcurra, E., GonzálezAbraham, C., Hak, J., Santiago, L.S., Sickman, J.O., 2011, Oceanographic anomalies and sea level rise drive mangroves inland in the pacific coast of Mexico: Journal of Vegetation Science, 22, 143-51.

McKee, K.L., Cahoon, D.R., Feller, I.C., 2007, Caribbean mangroves adjust to rising sea level through biotic controls on change in soil elevation: Global Ecology and Biogeography, $16,545-556$.

Martinuzzi, S., Gould, W.A., Lugo, A.E., Medina, E., 2009, Conversion and recovery of Puerto Rican mangroves: 200 years of change: Forest Ecology and Management, 257, 75-84.

McCloskey, T.A., Liu, K-B., 2013, Sedimentary history of mangrove cays in Turneffe Islands, Belize: evidence for sudden environmental reversals: Journal of Coastal Research, 29, 971-983.

Medina, E., Cuevas, Popp, E.M., Lugo, A.E., 1990, Soil salinity, sun exposure and growth of Acrostichum aureum, the mangrove fern: Botanical Gazette, 151, 41-49.

Mendelson, R., Bogard, S.J., Schwing, F.B., Palacios, D.M., 2005, Teaching old indices new tricks: state-space analysis of El Niño related climate indices: Geophysical Research Letters, 32, L07 709, doi:10.1029/2005GL022350.

Monacci, N.M., Meier-Grünhagen, U., Finney, B.P., Behling, H., Wooller, M.J., 2009, Mangrove ecosystem changes during the Holocene at Spanish Lookout Cay, Belize: Palaeogeography, Palaeoclimatology, Palaeoecology, 280, 37-46.

Monacci, N., Behling, H., Finney, B., MeirsGroenhagen, U., Wooller, M.J., 2011 , Paleoecology of mangroves along the Sibun River, Belize: Quaternary Research, 76, 220-228.

Parkinson, R.W., de Laune, R.D., White, J.R., 1994, Holocene Sea-Level rise and the fate of mangrove forests within the wider Caribbean region: Journal of Coastal Research, 10, 
1077-1086.

Parsons, J.J., 1985, San Andrés y Providencia: una geografía histórica de las islas colombianas del Caribe: Bogotá, El Ancora Editores, 194 p.

Peros, M.C., Reinhardt, E.G., Davis, A.M., 2007, A 6000-year record of ecological and hydrological changes from Laguna de la Leche, north coastal Cuba: Quaternary Research, 67, 69-82.

Raasveldt, H.C., Tomic, A., 1958, Lagunas colombianas. Contribución a la Geomorfología de la costa del mar Caribe con algunas observaciones sobre las Bocas de Ceniza: Revista de la Academia Colombiana de Ciencias Exactas, Físicas y Naturales, 10, 175-198.

Ramcharan, E.K., McAndrews, J.H., 2006, Holocene development of coastal wetland at Maracas bay, Trinidad, West Indies: Journal of Coastal Research, 22, 581-586.

Record, S., Charney N.D., Zakaria, R.M., Ellison, A.M., 2013, Projecting global mangrove species and community distributions under climate change: Ecosphere, 4, 34.

Rull, V., Vegas-Vilarrubia, T., Espinosa de Pernia, N., 1999, Palynological record of an Early-Mid Holocene mangrove in Eastern Venezuela. Implications for Sea-level rise and disturbance history: Journal of Coastal Research, 15, 496-504.

Serrano, B., 2004, The Sinú River delta on the northwestern Caribbean coast of Colombia: Bay infilling associated with delta development: Journal of South American Earth Science, 16, 623-631.

Smith, T.J. III, Robblee, M.B., Wanless, H.R., Doyle, T.W., 1994, Mangroves, hurricanes, and lightning strikes: Bioscience, 44, 256-262.

Snedaker, S.C., 1995, Mangroves and climate in the Florida and Caribbean region: Scenarios and hypotheses: Hydrobiology, 295, 43-49.

Sobrado, M.A., 2000, Relation of water transport to leaf gas exchange properties in three mangrove species: Trees, 14, 258-262.

Steffen, W., Grinevald, J., Crutzen, P., Mcneill, J., 2011, The Anthropocene: conceptual and historical perspectives: Philosophical Transactions of the Royal Society of America, 369, 842-867.

Suárez, J.A, Urrego, L.E, Osorio, A., Ruiz, H.Y., 2015, Oceanic and climatic drivers of mangrove changes in the Gulf of Urabá, Colombian Caribbean: Latin American Journal of Aquatic Research, 43, 972-985.

Torres, R., Otero, L., Franco, F., Marriaga, L., 2008, Comportamiento del nivel del mar en el litoral Caribe colombiano: Centro de Investigaciones Oceanográficas e Hidrográficas del Caribe. Boletín Científico CIOH, 26, 8-21.

Twilley, R.R., Chen, R., Rivera-Monroy, V., 1999, Formulating a model of mangrove succession in the Caribbean and Gulf of Mexico with emphasis on factors associated with global climate change: Current Topics in Wetland Biogeochemistry, 3, 118-141.

Urrego, L.E., Polania, J., Buitrago, M.F., Cuartas, L.F., Lema, A., 2009, Distribution of mangroves along environmental gradients on San Andrés Island (Colombian Caribbean): Bulletin of Marine Science, 85, 27-43.

Urrego, L.E., Correa-Metrio, A., González, C., Castaño, A.R., Yokoyama, Y., 2013, Contrasting responses of two Caribbean mangroves to sea-level rise in the Guajira Peninsula (Colombian Caribbean): Palaeogeography, Palaeoclimatology, Palaeoecology, 370, 92-102.

Woodroffe, G.D., Grindrod, J., 1991, Mangrove biogeography: the role of Quaternary environmental and sea-level change: Journal of Biogeography, 18, 479-492.

Wooller, M.J., Morgan, R., Fowell, S.J., Behling, H., Fogel, M., 2007, A multi-proxy peat record of Holocene mangrove paleoecology from Twin Cays, Belize: The Holocene, 17, 1129-1139.

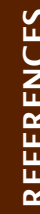

